\title{
Flow Injection Spectrophotometric Determination of Fenoxaprop-p-ethyl Herbicide in Different Grain Samples after Derivatization
}

\author{
Jasmin Shah,* M. Rasul Jan, Mian Muhammad and Farhat-un-Nisa Shehzad \\ Institute of Chemical Sciences, University of Peshawar, N.W.F.P., Pakistan
}

\begin{abstract}
Propomos um método espectrofotométrico para a determinação do herbicida fenoxaprop-p-etil, usando injeção em fluxo.O fenoxaprop-p-etil foi convertido num ácido hidroxamico, na presença de hidroxilamina dihidrocloridrica em meio alcalino. $\mathrm{O}$ ácido hidroxâmico obtido reagiu com ferro(III) formando um complexo hidroxamato de ferro(III), vermelho. A absorbância do complexo foi medida a $500 \mathrm{~nm}$ em sistema de injeção em fluxo. O método apresenta linearidade entre 1,0-20,0 $\mu \mathrm{g} \mathrm{mL} \mathrm{m}^{-1}$ com absortividade molar de $1,81 \times 10^{4} \mathrm{~L} \mathrm{~mol}^{-1} \mathrm{~cm}^{-1}$. O limite de detecção e o limite de quantificação encontrados foram $0,29 \pm 0,1 \mu \mathrm{g} \mathrm{mL^{-1 }}$ e $0,96 \pm 0,1 \mu \mathrm{g} \mathrm{mL} \mathrm{mL}^{-1}$ respectivamente. Médias similares de limite de detecção e limite de quantificação foram encontradas para a determinação de residuos, entre $0,35^{-1}$ e $0,45 \mu \mathrm{g} \mathrm{g}^{-1}$ respectivamente para grãos de trigo, e 1,2 e $1,5 \mu \mathrm{g} \mathrm{g}^{-1}$ respectivamente para grãos de cevada. A velocidade de determinação foi de 90 amostras $\mathrm{h}^{-1}$. O método foi aplicado com sucesso em amostras de diferentes grãos.
\end{abstract}

A spectrophotometric method for determination of fenoxaprop-p-ethyl herbicide using flow injection system has been proposed. The fenoxaprop-p-ethyl was converted into hydroxamic acid in the presence of hydroxylamine hydrochloride in alkaline media. The hydroxamic acid produced was further reacted with iron(III) to form red color tris iron hydroxamate complex. The absorbance of the complex was measured at $500 \mathrm{~nm}$ using flow injection system. The method shows a linear range between 1.0-20.0 $\mu \mathrm{g} \mathrm{mL}^{-1}$ with molar absorptivity of $1.81 \times 10^{4} \mathrm{~L} \mathrm{~mol}^{-1} \mathrm{~cm}^{-1}$. The limit of detection and limit of quantification were calculated and found to be $0.29 \pm 0.1 \mu \mathrm{g} \mathrm{mL}^{-1}$ and $0.96 \pm 0.1 \mu \mathrm{g} \mathrm{mL}-1$ respectively. Similarly the average limit of detection and limit of quantification were calculated for residue determination and were found 0.35 and $0.45 \mu \mathrm{g} \mathrm{g} \mathrm{g}^{-1}$ respectively for wheat grains and 1.2 and $1.5 \mu \mathrm{g} \mathrm{g}^{-1}$ respectively for barley grains. The sample through put was 90 samples $^{-1}$. The method was successfully applied to different grain samples.

Keywords: fenoxaprop-p-ethyl, hydroxamic acid, iron(III), flow injection, spectrophotometric method

\section{Introduction}

Fenoxaprop-p-ethyl [(+)-ethyl-2-[4[(6-chloro-2benzoxazolyl)oxy] phenoxy] propionate] belongs to an aryloxyphenoxypropionate herbicide group which is used for the control of annual and perennial grass weeds in cotton, potato, wheat and soybeans as a selective graminicide. ${ }^{1,2}$ Fenoxaprop-p-ethyl control weeds due to inhibition of acetyl-CoA carboxylase found both in mammalian liver and plant chloroplast. ${ }^{3,4}$ Therefore, the toxicity of fenoxaprop-p-ethyl makes it impossible to underestimate the toxicity risk to human beings.

Most of the methods reported for determination of fenoxaprop-p-ethyl are chromatographic like HPLC, ${ }^{5-8}$

\footnotetext{
*e-mail: jasminshah2001@yahoo.com
}

HPTLC, ${ }^{9}$ and GC-ECD, ${ }^{10,11}$ No spectrophotometric method has been reported in the literature so far.

Flow injection analysis (FIA) being simple, versatile and having high sample through put, is predominantly used in conjunction with UV/Vis spectrophometric detection for the analysis of various environmental, clinical, and agricultural samples. ${ }^{12}$ This technique has been widely used for the determination of herbicides like fluroxypyr, ${ }^{13}$ and 2,4-D, ${ }^{14}$ in maize and wheat with spectrophotometric detection and mecoprop, 2,4-D and sulfonylurea with micellar-enhanced photochemically induced fluorescence (MEPIF) detection ${ }^{15,16}$ in spiked water samples.

The purpose of the present study was to develop simple, rapid and sensitive method for the analysis of fenoxapropp-ethyl using online reaction in a flow injection system. The method is based on conversion of fenoxaprop-p-ethyl into 
hydroxamic acid and further complexation of hydroxamic acid with iron(III) to form red colored iron hydroxamate complex in the flow system. The absorbance of the complex was measured at $500 \mathrm{~nm}$.

\section{Materials and Methods}

\section{Instruments}

UV/Visible Spectrophotometer (UNICO, UV-2100 United Products and Instruments Inc, Dayton, NJ, USA), Pump (Model 124869 MP-1 pump Spectra/chrom Spectrum), Silicon tube $(1.71 \mathrm{~mm}$, i.d), V-450 6-port injection valve (Upchurch Scientific Inc, USA), PTFE Tubing (1.19 mm, i.d., Becton Dickson, USA) were used for flow injection analysis.

\section{Reagents}

All reagents used were of analytical reagent-grade purity or similar grade. Hydroxylamine hydrochloride (MP Biomedicals, LLC 1263 South Chillicothe Rd Aurora, Ohio 44202), sodium hydroxide, hydrochloric acid, ethanol, and ferric chloride (Merck, Darmstadt Germany) were used during this work. Reference standard of fenoxapropp-ethyl herbicide was purchased from Dr Ehrenstorfer GmbH (Augsburg, Germany). Reagent grade acetone (BDH Laboratory suppliers Poole, England) and methanol (Merck, Darmstadt Germany) were used for extraction of herbicide from grain samples. Commercial formulation containing (6.9\%) fenoxaprop-p-ethyl (FE) was purchased from the local market. All the solutions used were stable at room temperature.

\section{Solutions}

i) Standard fenoxaprop-p-ethyl (FE) solution: A standard stock solution of fenoxaprop-p-ethyl (FE) $\left(350 \mu \mathrm{g} \mathrm{mL} \mathrm{m}^{-1}\right)$ was prepared by dissolving $0.035 \mathrm{~g}$ of the authentic sample in $20 \mathrm{~mL}$ methanol and diluted to $100 \mathrm{~mL}$ with methanol. ii) Hydroxylamine hydrochloride solution: Hydroxylamine hydrochloride stock solution $\left(0.5 \mathrm{~mol} \mathrm{~L}^{-1}\right)$ was prepared by dissolving $3.475 \mathrm{~g}$ of the reagent in $30 \mathrm{~mL}$ methanol and diluted to $100 \mathrm{~mL}$ with methanol. iii) Sodium hydroxide and hydrochloric acid solutions: Sodium hydroxide $\left(6 \mathrm{~mol} \mathrm{~L}^{-1}\right)$ and hydrochloric acid $\left(1 \mathrm{~mol} \mathrm{~L}^{-1}\right)$ solutions were prepared by dissolving appropriate amounts in distilled water and diluted to $100 \mathrm{~mL}$ with distilled water. $i v$ ) Ferric chloride solution: Ferric chloride solution (5\%) was prepared by dissolving $5 \mathrm{~g}$ in $30 \mathrm{~mL}$ distilled water and diluted to $100 \mathrm{~mL}$.

\section{Batch analysis}

In batch analysis, $1.0 \mathrm{~mL}$ was taken, from a standard stock solution of FE $\left(350 \mu \mathrm{gL}^{-1}\right)$, in a $100 \mathrm{~mL}$ titration flask followed by the addition of $1 \mathrm{~mL}$ of $0.1 \mathrm{~mol} \mathrm{~L}^{-1}$ hydroxylamine hydrochloride solution. To this mixture $0.3 \mathrm{~mL}$ of sodium hydroxide solution $\left(6 \mathrm{~mol} \mathrm{~L}^{-1}\right)$, was added and equilibrated for $5 \mathrm{~min}$ for completion of reaction. The medium was acidified by adding $2 \mathrm{~mL}$ of hydrochloric acid $\left(1 \mathrm{~mol} \mathrm{~L}^{-1}\right)$ followed by the addition of $2 \mathrm{~mL}$ ethanol. Then $0.3 \mathrm{~mL}$ of ferric chloride solution (5\%) was added. The resulting solution of the red colored complex was transferred to a $10 \mathrm{~mL}$ volumetric flask and diluted to $10 \mathrm{~mL}$ with ethanol. The absorption spectrum of the solution was measured at $500 \mathrm{~nm}$.

The physical and chemical variables were optimized for the reaction in FI system by changing one variable and keeping the other variables constant. The maximum absorbance of the complex was measured at $500 \mathrm{~nm}$.

\section{Flow injection analysis}

For flow injection analysis, a three channel FIA system was arranged (Figure 1). In the FI manifolds in reagent stream F1 a mixture of $\mathrm{NH}_{2} \mathrm{OH} \cdot \mathrm{HCl}\left(0.1 \mathrm{~mol} \mathrm{~L}^{-1}\right)$ and $\mathrm{NaOH}\left(6 \mathrm{~mol} \mathrm{~L}^{-1}\right)$ in a ratio of 4:1 was pumped. Sample solution of fenoxaprop-p-ethyl was injected into the F1 stream through the injection valve in a $300 \mu \mathrm{L}$ injection loop. The hydroxamic acid thus formed was then acidified with 1:1 mixture of $\mathrm{HCl}\left(1 \mathrm{~mol} \mathrm{~L}^{-1}\right)$ and ethanol flowing down in the reagent stream F2. Finally complexation of the acidic hydroxamic acid solution with iron(III) resulted in the stream of $\mathrm{FeCl}_{3}$ solution flowing in $\mathrm{F} 3$. The red colored complex formed was passed through a flow through cell and the absorbance continuously measured at $\lambda_{\text {max }} 500 \mathrm{~nm}$ by UNICO UV-2100 Spectrophotometer.

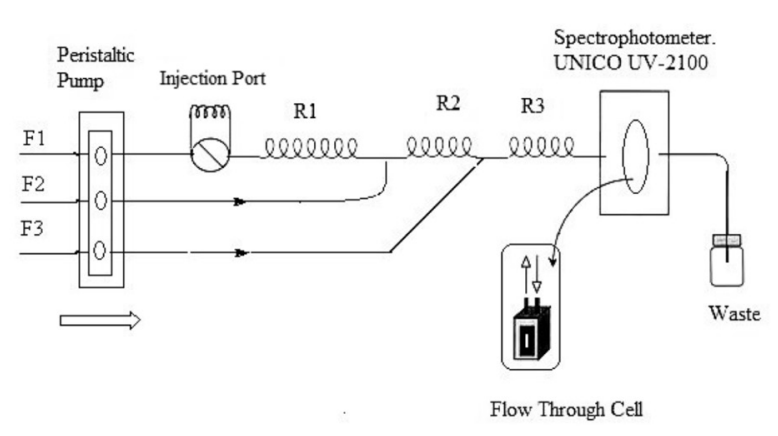

Figure 1. Scheme of manifold flow injection system for flow injection spectrophotometric determination of FE. F1; Reagent- $1\left(\mathrm{NH}_{2} \mathrm{OH} \cdot \mathrm{HCl}\right.$ $+\mathrm{NaOH}), \mathrm{F} 2$; Reagent-2 $\left(\mathrm{HCl}+\mathrm{C}_{2} \mathrm{H}_{5} \mathrm{OH}\right), \mathrm{F} 3$; Reagent-3 $\left(\mathrm{FeCl}_{3}\right), \mathrm{R} 1$; Reaction coil-1(Hydroxamic acid formation), R2; Reaction coil-2 (Acidification), R3; Reaction coil-3 (Complex formation). 
Recovery \%

Samples of wheat and barley grains were collected from crop field where no spray of the herbicide was done. Control samples ( $10 \mathrm{~g})$ of each were separately placed in bottles and known concentration of fenoxaprop-p-ethyl solution was added to adjust the concentration level of 5, 10, $15 \mu \mathrm{g} \mathrm{g}^{-1}$. The samples were homogenized by mechanical shaking for uniform mixing and kept for $24 \mathrm{~h}$ at ambient temperature. The homogenized samples were extracted for 60 min with $25 \mathrm{~mL}$ of each, methanol and acetone. Extraction was repeated three times. The percent recovery was evaluated by the proposed method, using both batch and flow injection analysis. Each recovery was carried out in triplicate.

\section{Determination of residue in gain samples}

The fenoxaprop-p-ethyl residue in barely grains sample; collected from a crop field upon which the herbicide was sprayed as a pilot project, was determined by standard addition method. Six samples of barely grains (10 g each) were taken in bottles and spiked with a known concentration of standard fenoxaprop-p-ethyl solution. The bottles were uniformly shaken manually for proper mixing and kept for $24 \mathrm{~h}$. The herbicide was extracted with $25 \mathrm{~mL}$ of solvent (acetone and methanol). The extract of acetone was evaporated at room temperature and the residue was dissolved in $25 \mathrm{~mL}$ methanol. The concentrations of the analyte in the extracts were then evaluated by the proposed batch and FIA method. The residue of herbicide present in the sample was determined from the difference of the concentration of added standard solution and the concentration of herbicide in spiked sample.

\section{Results and Discussion}

The chemical structure of fenoxaprop-p-ethyl contains a terminal ester group like propanate which can be easily converted into hydroxyl propanamide (hydroxamic acid) with the help of hydroxylamin hydrochloride in alkaline media. The hydroxamic acid was used as a ligand with iron(III) in acidic media and resulted in a red colored iron(III) hydroxamate complex (Figure 2). The reaction is fast at room temperature therefore applied in the flow injection system for determination of fenoxaprop-p-ethyl herbicide.

The results for the optimization of hydroxylamin hydrochloride concentration are given in Figure 3. The absorbance increased from 0.025 to $0.1 \mathrm{~mol} \mathrm{~L}^{-1}$ hydroxylamine hydrochloride solution and small decrease in absorbance was observed at higher concentration.
Step1. Hydroxamic acid formation from fenoxaprop-p-ethyl
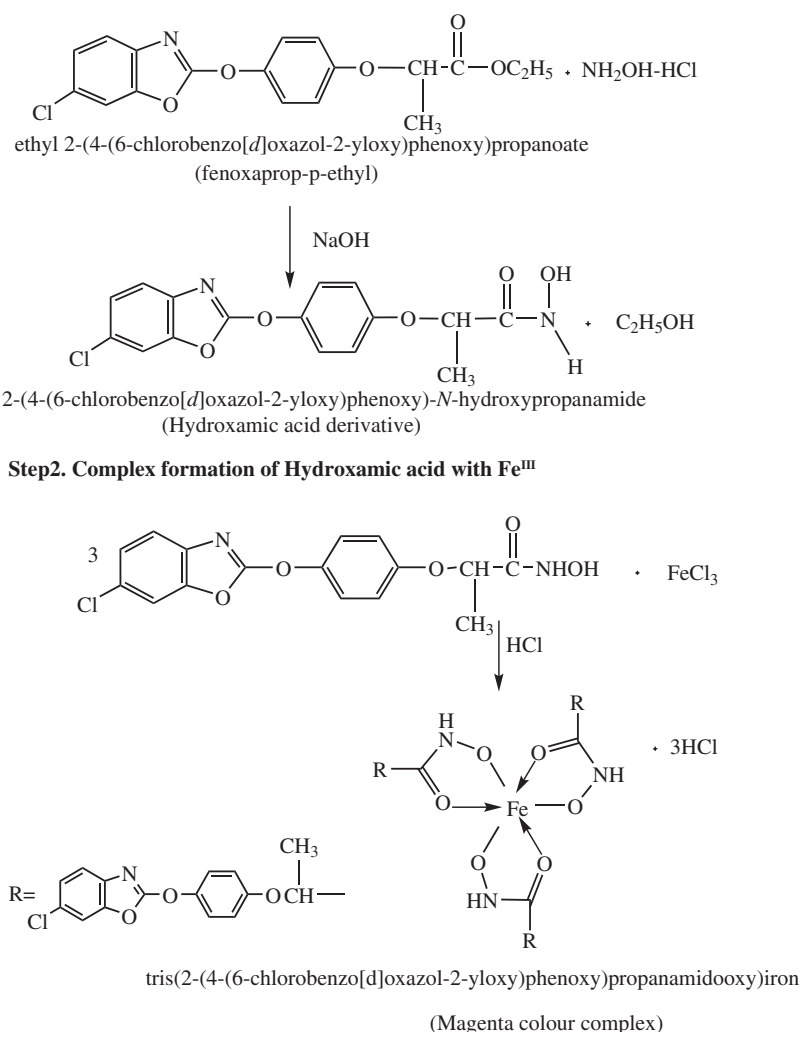

Figure 2. Proposed reaction mechanism for determination of fenoxapropp-ethyl by flow injection spectrophotometric method.

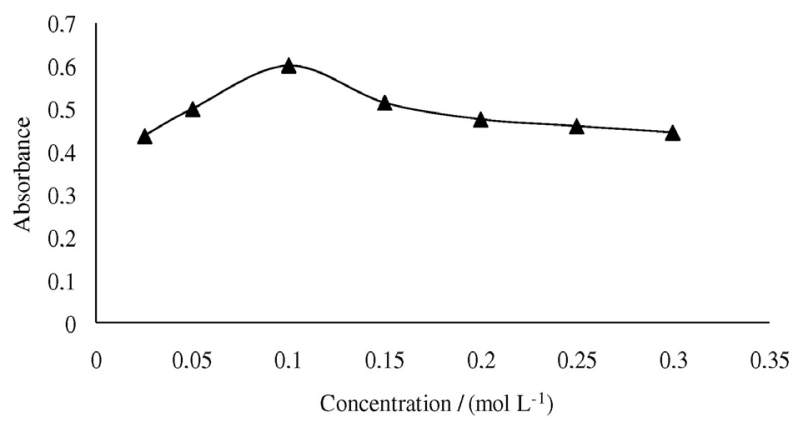

Figure 3. Effect of hydroxylamine hydrochloride concentration on hydroxamic acid formation from fenoxaprop-p-ethyl herbicide.

Hydroxylamin hydrochloride reacts with fenoxaprop-pethyl in alkaline media and sodium hydroxide concentration was optimized in the range of 1.0 to $8.0 \mathrm{~mol} \mathrm{~L}^{-1}$. Reaction starts with $4.0 \mathrm{~mol} \mathrm{~L}^{-1}$ sodium hydroxide solution (Figure 4) and maximum absorbance of the complex was found at $6.0 \mathrm{~mol} \mathrm{~L}^{-1}$ sodium hydroxide solutions.

The hydroxamic acid formed from fenoxaprop-p-ethyl herbicide was used as a ligand and reacted with iron(III) for complex formation. Hydroxamic acid reacts with iron(III) in acid media and hydrochloric acid was used to adjust the acidity of solution. The concentration of hydrochloric acid was optimized from 0.6 to $3.5 \mathrm{~mol} \mathrm{~L}^{-1}$. The complex 


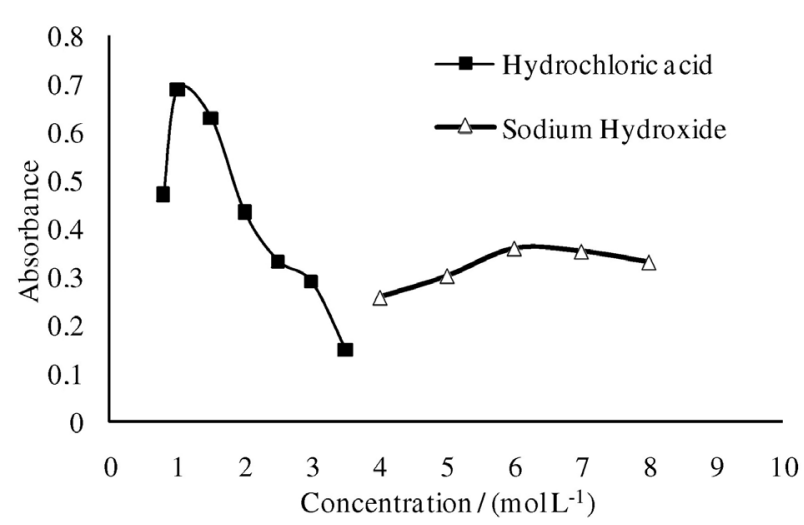

Figure 4. Effect of sodium hydroxide and hydrochloric acid concentration on reaction of hydroxylamine hydrochloride with fenoxaprop-p-ethyl herbicide.

formation started with $0.8 \mathrm{~mol} \mathrm{~L}^{-1}$ hydrochloric acid solution and increased up to $1.0 \mathrm{~mol} \mathrm{~L}^{-1}$ (Figure 4). Beyond $1.0 \mathrm{~mol} \mathrm{~L}^{-1}$ concentration of acid solution the absorbance decreased with increase in concentration. Therefore further analysis was performed at $1.0 \mathrm{~mol} \mathrm{~L}^{-1}$ solution of hydrochloric acid.

The stoichiometric ratio of the hydroxamic acid formed from fenoxaprop-p-ethyl to iron(III) was established by the Job's method of continuous variation. ${ }^{17,18}$ The composition of the complex was found to be [hydroxamic acid: iron(III)] $3: 1$ that is three mole of ligand react with one mole of iron(III). The calculated formation constant of the complex was $9.74 \times 10^{12}$, which shows high stability of complex.

The physical variables like reaction coil length (Figure 5) and flow rate (Figure 6) were optimized. The effect of reaction coil length R1 was studied from 15 to $100 \mathrm{~cm}$ for hydroxamic acid formation from fenoxapropp-ethyl with hydroxylamine hydrochloride in alkaline media. Maximum absorbance of reaction was found at $25 \mathrm{~cm}$ coil length which indicates rapid reaction between fenoxaprop-p-ethyl and hydroxylamine hydrochloride. The second reaction coil R2 was also optimized for changing the media from alkaline to acidic. The acidity of the reagents was found maximum with $25 \mathrm{~cm}$ reaction coil length. For complex formation the reaction coil R3 was also investigated and maximum absorbance of complex was found with $40 \mathrm{~cm}$ coil length. The results indicated that hydroxamic acid and complex formation reactions are fast and reproducible in the FI system. Flow rate of the FI system for reaction was studied in the range of 1.0 to $5.0 \mathrm{~mL} \mathrm{~min}{ }^{-1}$ (Figure 6). Increase in absorbance was observed when the flow rate increased from 1.0 to $3.0 \mathrm{~mL} \mathrm{~min}{ }^{-1}$. Above $3.0 \mathrm{~mL} \mathrm{~min}^{-1}$ decreased absorbance with higher flow rates due to incomplete reaction. With this flow rate, a sampling rate of 90 samples $\mathrm{h}^{-1}$ was achieved.

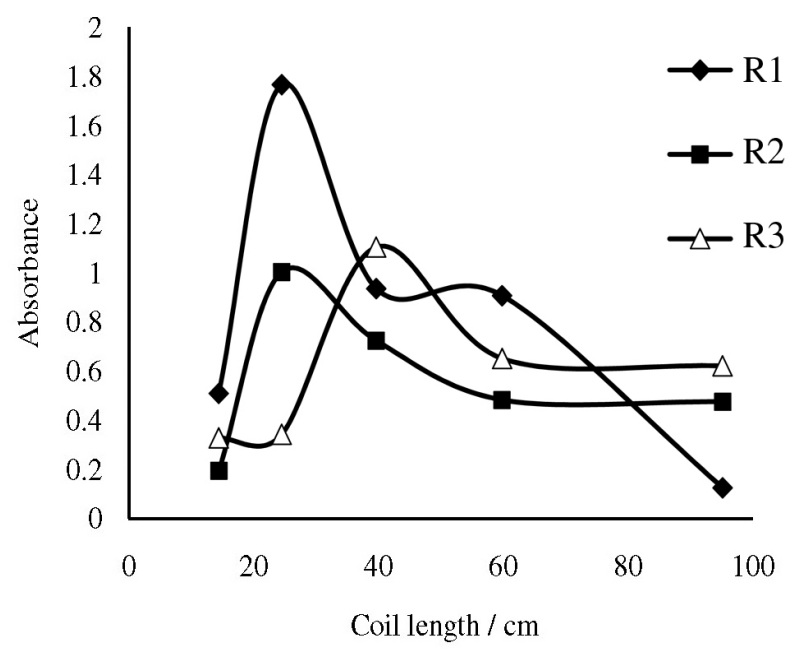

Figure 5. Effect of reaction coil length on reaction in flow injection analysis.

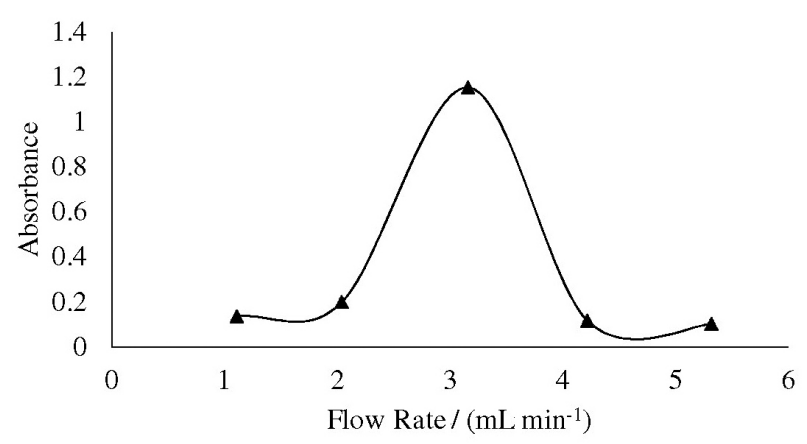

Figure 6. Effect of flow rate on reaction in flow injection analysis.

\section{Analytical characteristics}

The optimized parameters both for batch and FI methods are given in Table 1. The applicability of Beer's law by batch and FIA system was checked. A linear relation was observed in the concentration range of 2.0-50 $\mu \mathrm{g} \mathrm{mL}^{-1}$ and 1.0-20.0 $\mu \mathrm{g} \mathrm{mL}-1$ for batch and FI methods respectively. The molar absorbtivity of the resulting complex was found to be $1.85 \times 10^{3} \mathrm{~L} \mathrm{~mol}^{-1} \mathrm{~cm}^{-1}$ with batch method and $1.81 \times 10^{4} \mathrm{~L} \mathrm{~mol}^{-1} \mathrm{~cm}^{-1}$ with FIA. The Limit of detection and quantification was calculated at lower concentration that

Table 1. Characteristics of the proposed method.

\begin{tabular}{lcc}
\hline Parameter & FIA & Batch \\
\hline$\lambda_{\max }(\mathrm{nm})$ & 500 & 500 \\
Molar absorptivity $(\varepsilon)\left(\mathrm{L} \mathrm{mol}^{-1} \mathrm{~cm}^{-1}\right)$ & $1.81 \times 10^{4}$ & $1.85 \times 10^{3}$ \\
$\mathrm{RSD}(\%)$ & 4.34 & 3.14 \\
Limit of Detection $\left(\mu \mathrm{g} \mathrm{mL}^{-1}\right)$ & 0.29 & 0.45 \\
Limit of Quantification $\left(\mu \mathrm{g} \mathrm{mL}^{-1}\right)$ & 0.96 & 1.49 \\
Correlation Coefficient & 0.998 & 0.997 \\
Slope & 0.0179 & 0.0040 \\
Intercept & 0.029 & 0.00 \\
\hline
\end{tabular}


Table 2. Recovery \% of fenoxaprop-p-ethyl herbicide from wheat and barley grains using the proposed method

\begin{tabular}{|c|c|c|c|c|c|c|}
\hline \multirow[t]{2}{*}{ Sample } & \multirow[t]{2}{*}{ Eluent } & \multirow[t]{2}{*}{$\begin{array}{l}\text { Added } \\
\left(\mu g g^{-1}\right)\end{array}$} & \multicolumn{2}{|c|}{ Found $\left(\mu \mathrm{g} \mathrm{g}^{-1}\right)$} & \multicolumn{2}{|c|}{$\begin{array}{c}\text { Average } \\
\text { Recovery } \% \pm \mathrm{RSD}\end{array}$} \\
\hline & & & Batch & FIA & Batch & FIA \\
\hline \multirow[t]{6}{*}{ Wheat grains } & Methanol & 5 & 4.4 & 4.5 & $88 \pm 3.0$ & $90 \pm 1.0$ \\
\hline & & 10 & 8.5 & 9.0 & & \\
\hline & & 15 & 13.7 & 13.6 & & \\
\hline & Acetone & 5 & 4.5 & 4.5 & $89 \pm 3.0$ & $92 \pm 1.0$ \\
\hline & & 10 & 8.6 & 9.3 & & \\
\hline & & 15 & 13.7 & 14.0 & & \\
\hline \multirow[t]{6}{*}{ Barely grains } & Methanol & 5 & 4.3 & 4.4 & $87 \pm 0.0$ & $88 \pm 1.7$ \\
\hline & & 10 & 8.6 & 9.0 & & \\
\hline & & 15 & 13.0 & 13.1 & & \\
\hline & Acetone & 5 & 4.4 & 4.6 & $88 \pm 0.5$ & $92 \pm 0.6$ \\
\hline & & 10 & 8.7 & 9.2 & & \\
\hline & & 15 & 13.3 & 13.8 & & \\
\hline
\end{tabular}

can be measured with acceptable precision and accuracy and found to be $0.45 \pm 0.15,1.5 \pm 0.22 \mu \mathrm{g} \mathrm{mL}^{-1}$, and $0.3 \pm 0.01,0.96 \pm 0.1 \mu \mathrm{g} \mathrm{mL}-1$ for batch and FIA methods respectively. The sensitivity achieved with the FI method is higher than with the batch method. The advantages of the developed FI method are high sensitivity, low reagent waste and high sample through put.

\section{Analysis of samples}

The validity of the proposed FI method was checked using the standard addition method. The recovery $\%$ of fenoxaprop-p-ethyl herbicide from wheat and barley samples was determined and the results are given in Table 2. For extraction from wheat and barley grains different solvents like methanol, acetone, dichloromethane and 1:1 mixture of acetone and dichloromethane were used and maximum extraction was achieved with acetone and methanol. Therefore, for residue determination methanol and acetone were used as extracting solvents. The average recoveries from wheat grains with acetone as eluent were $89.0 \pm 3.0 \%$ and $92.0 \pm 1.0 \%$ while with methanol it was $88.0 \pm 3.0 \%$ and $90.0 \pm 1.0 \%$ for batch and FI methods respectively. Similarly the recoveries were found $88.0 \pm 0.5 \%$ and $92.0 \pm 0.6 \%$ for barley grains with acetone as eluent and $87.0 \pm 0.0 \%$ and $88.0 \pm 1.7 \%$ with methanol, using batch and FI methods respectively. The average limit of detection (LOD) and limit of quantification (LOQ) calculated is 0.35 and $1.2 \mu \mathrm{g} \mathrm{g}^{-1}$ respectively, for wheat grains and 0.45 and $1.5 \mu \mathrm{g} \mathrm{g}^{-1}$ respectively for barley grains. The proposed method was also applied for the determination of fenoxaprop-p-ethyl residue in barley grains and was found $3.0 \pm 0.5 \mu \mathrm{g} \mathrm{g}^{-1}$ for batch method and $2.9 \pm 0.15 \mu \mathrm{g} \mathrm{g}^{-1}$ for FI method (Table 3).
Table 3. Residue determination in barely sample by the proposed method.

\begin{tabular}{lccc}
\hline $\begin{array}{l}\text { Method of } \\
\text { Analysis }\end{array}$ & $\begin{array}{c}\text { Conc. added } \\
\left(\mu \mathrm{g} \mathrm{g}^{-1}\right)\end{array}$ & $\begin{array}{c}\text { Total Conc. } \\
\text { Found } \\
\left(\mu \mathrm{g} \mathrm{mL}^{-1}\right)\end{array}$ & $\begin{array}{c}\text { Residue } \\
\left(\mu \mathrm{g} \mathrm{g}^{-1}\right)\end{array}$ \\
\hline \multirow{4}{*}{ Batch } & 7.60 & 9.20 & \\
& 8.20 & 8.80 & $3.0 \pm 0.5$ \\
\hline \multirow{3}{*}{ FIA } & 8.00 & 9.40 & \\
& 8.25 & 9.40 & \\
\hline
\end{tabular}

\section{Conclusions}

Flow injection spectrophotometric method has been developed for determination of fenoxaprop-p-ethyl herbicide based on formation of hydroxamic acid from fenoxaprop-p-ethyl and further reaction of hydroxamic acid with iron(III) to form a red coloured complex. The flow injection spectrophotometric method has low detection limit and high sample throughput. The method is applicable to environmental samples and applied to wheat and barley grains with recoveries in the range of $88.0 \pm 1.7 \%$ to $92.0 \pm 1.0 \%$. Compared to gas chromatographic and liquid chromatographic methods the proposed method is simple, sensitive and reproducible.

\section{References}

1. Cocker, K. M.; Moss, S. R.; Coleman, J. O. D.; Pestic. Biochem. Physiol. 1999, 65, 169.

2. Kim, J.; Oh, J.; Kim, T.; Pyon, J. Y.; Cho, K. Y.; Weed Biol. Manag. 2005, 5, 39.

3. Marles, M. M.; Devine, M. D.; Halt, J. C.; Pestic. Biochem. Physiol. 1993, 46, 7. 
4. Pornprom, T.; Mahatamnuchoke, P.; Usui, K.; Pest Manage. Sci. 2006, 62, 1109.

5. Rosales-Conrado, N.; Leon-Gonzales, M. E.; Perez-Arribas, L. V.; Polo-Diez, L. M.; Anal. Chim. Acta 2002, 470, 147.

6. Celi, L.; Negre, M.; Gennari, M.; Pestic. Sci. 1993, 38, 43.

7. Mojtahedi, M. M.; Chalavi, S.; Ghassempour, A.; Tabar-Heydar, K.; Sharif, S. J.; Malekzodeh, M.; Aboul-Enein, H. Y.; Biomed. Chromatogr. 2007, 21, 234.

8. Lin, J.; Chen, J.; Cai, X.; Qiao, X.; Huang, L.; Wang, D.; Wang, Z.; J. Agric. Food Chem. 2007, 55, 7626.

9. Song, L.; Hua, R.; Zhao, Y.; J. Hazard. Mater. 2005, 118, 247.

10. Zhu, F. G. N.; Liu, H. J.; Zhu, J. W.; Pesticide 2000, 5, 19.

11. Diez, C.; Barrado, E.; Marinero, P.; Snaz, M.; J. Chromatogr. A 2008, 1180, 10 .
12. Zhang, J. Z.; Anal. Sci. 2006, 22, 57.

13. Shah, J.; Jan, M. R.; Bashir, N.; Anal. Sci. 2006, 22, 145.

14. Shah, J.; Jan, M. R.; Bashir, N.; J. Chin. Chem. Soc. 2006, 53, 845.

15. Garcia-Campana, A. M.; Aaron, J-J.; Bosque-Sendra, J. M.; Talanta 2001, 55, 531.

16. Coly, A.; Aaron, J-J.; Anal. Chim. Acta 1999, 392, 255.

17. Inczedy, I.; Analytical Applications of Complex Equilibria, Ellis Horwood Ltd.; England, 1976; p.137.

18. Huang, C. Y.; Zhou, R. X.; Yang, D. C. H.; Chock, P. B.; Biophys. Chem. 2003, 100, 143.

Submitted: November 16, 2009

Published online: June 29, 2010 